\title{
Mapping the value of ecosystem services: A case study from the Austrian Alps
}

\author{
A. Paletto, C. Geitner, G. Grilli, R. Hastik, F. Pastorella, L. Rodrìguez Garcia
}

Paletto A., Geitner C., Grilli G., Hastik R., Pastorella F. , Rodrìguez Garcìa L., 2015. Ma-pping the value of ecosystem services: a case study from the Austrian Alps. Ann. For. Res. 58(1): 157-175.

Abstract. Ecosystem services (ES) are considered the conditions and processes through which natural ecosystems sustain and fulfil human life. In the decision making process related to the natural resources management, two key-aspects must be taken into account: the economic value of the benefits provided by ES (provisioning, regulating and cultural services) and the spatial distribution of these benefits. The purpose of the paper is to develop a method aimed to capture the economic value of the benefits provided by ES, in order to support the decision makers in the natural resources management. ES are not homogeneous across landscapes nor in space. Consequently, gaining knowledge on the spatial distribution of the economic relevance of ES is a fundamental information to target management actions. This method was tested in a case study in the Austrian Alps (Leiblachtal area in Vorarlberg region), characterized by a high importance of forests and grasslands. The results show that the highest economic values could be achieved for the provisioning services with a range between $200 € /$ ha year and 1,400 $€ /$ ha year. The regulating services have also important economic values, but strongly localized in specific areas (i.e. protective forests against natural hazards). The economic values of the cultural services are influenced by the preferences of tourists and varies between $5 € /$ ha year to $60 € /$ ha year. The method allowed us to reveal the spatial heterogeneity of provisioning, regulating and cultural ES, depending on the ecological characteristics of the site. Keywords provisioning services, regulating services, cultural services, economic valuation, meta-analysis, Benefit Transfer method, Alpine Region, Leiblachtal (Austria).

Authors. Alessandro Paletto (alessandro.paletto@entecra.it); Laura Rodrìguez Garcìa - Council for Agricultural Research and Economics - Forest Monitoring and Planning (MPF), Piazza Monsignor Nicolini 6, 38123 Villazzano di Trento (Italy); Clemens Geitner, Richard Hastik - Institute of Geography, University of Innsbruck (Austria), Innrain 52f; 6020 Innsbruck; Gianluca Grilli - Institute for Renewable Energy, European Academy of Bolzano (EURAC) and Department of Civil, Environmental and Mechanical Engineering, University of Trento, via Mesiano 77, 38123 Trento (Italy); Fabio Pastorella - European Forest Institute (EFI) Project Center "MOUNTFOR", Via E. Mach, 138010 San Michele A/A (Italy).

Manuscript received November 05, 2014; revised February 03, 2015; accepted February 10, 2015; online first February 13, 2015. 


\section{Introduction}

Natural ecosystems provide a multitude of benefits to human society (MEA 2005), such as natural resources (food, water, wood for construction and for bio-energy, fodder and medicinal plants), pollination, clean water provision, protection against natural risks (landslides, flooding, rockfalls and avalanches), carbon sequestration and storage, tourism and recreation (Fisher et al. 2009, Vihervaara et al. 2010, Paletto et al. 2012). At the end of ' 70 years, Westman (1977) asserted that the comprehensive value of benefits that ecosystems provide - defined as nature's services - could potentially be accounted in order to better address policy and management decisions. Afterwards, the concept of ecosystem services (ES) was first introduced in the early ' 80 by Ehrlich and Ehrlich (1981). Subsequently, during the '90 years the ES concept has been established in the scientific debate due to several authors that applied this concept through different perspectives of analysis (Mooney \& Ehrlich 1997, Vitousek et al. 1997). With the Millennium Ecosystem Assessment (MEA) in 2005 the concept achieved a breakthrough also beyond the scientific discourse. For the MEA (2005), ES are considered the conditions and processes through which natural ecosystems sustain and fulfil human life (Daily 1997) and the benefits human populations derive, directly or indirectly, from ecosystem functions (Costanza et al. 1997).

In the last decade - under the impulse of the Millennium Ecosystem Assessment (MA, 2005) and the Economics of Ecosystems and Biodiversity (TEEB 2010) initiative - the ES were integrated in the EU political agenda (environmental, agricultural and biodiversity policies) (Maes et al. 2012). In particular, the EU Biodiversity Strategy 2020 integrated the sustainable use of ES for economic growth with a non-utilitarian conservation approach (EC 2011).

The MEA classified the ES based on their functions in four categories: (1) provisioning services, referring to the goods that can be harvested such as food, timber, fodder, water provision, (2) regulating services, considering the role of ecosystem in the regulation of ecological processes (i.e. water and climate regulation), (3) cultural services, involving the non-material benefits provided by ecosystems (i.e. recreational opportunities, cultural and spiritual values), and (4) supporting services such as plant production and nutrient cycling. Subsequently, De Groot et al. (2010) reclassified ES replacing supporting services with habitat services (i.e. nursery habitat, gene pool protection). This reclassification of ES which excluded the supporting services has been designed to prevent double counting (Hein et al. 2006).

Referring to Eade and Moran (1996), in the decisions related to the natural resources management two key-aspects must be taken into account with special regards on different ES categories (Eade \& Moran 1996): the economic value of the benefits provided by ES and the spatial distribution of these benefits.

Still today, the economic value of ecosystem goods and services are often little considered in decision making due to a lack of awareness of the attributed values for human well-being (Grêt-Regamey et al. 2008). Nevertheless, problems exist to define their exact value, for instance to compare exploitation and conservation costs of natural resources on the long term. In order to overcome this limit, many methods have been developed and applied for assessing the economic values of different ES (Mitchell \& Carson 1989, Hanemann 1994, Garrod \& Willis 1999, Rosenberger \& Loomis 2001). These methods - i.e. contingent valuation, choice experiment - allow the assignment of a monetary value to ES without a market, such as climate and water regulation, protection against natural risks, and biodiversity (Heal et al. 2005). Valuing ES is extremely beneficial for improving the standard national accounting. The "System of National 
Accounts" (SNA) - introduced in the early 50 's - is nowadays thought to be too weak for describing the real status of the national assets. In particular, the focus of the criticism is related to the environmental resources, which are undervalued by SNA but they have a great importance in the framework of sustainability. In the recent decades, it was pointed out that integrating SNA with environmental considerations may be useful for highlighting the interactions between the economic system and the environment (Scarpa 1993) and understand how natural capital is depleted by economic activities. The evaluation of non-market benefits of forest ES goes in this direction, providing additional information to better understand the worth of natural capital of a region, which is not only given by the marketable goods but also by passive use and non-use values (Adamowicz et al. 1998). The new approach of the green accounting, foresees that any change in the stock of natural resources should be carefully considered, because it affects the future generation of both market and non-market benefits.

ES are not homogeneous across landscapes nor in space (Fisher et al. 2009). In other words, ES are linked to the spatial dimension of the defined zone in which those services are provided (Busch et al. 2012). The quantification and mapping of ES is considered a fundamental requirement for planning at the landscape scale (i.e. land use changes, renewable energies development, silvicultural treatments) (Hauck et al. 2013). The approaches and indicators used for a spatial mapping of ES has been documented in detail by literature reviews (Egoh et al. 2012, Maes et al. 2012, Martínez-Harms \& Balvanera 2012).

Starting from these considerations, the main objective of the paper is to develop a useful method to provide accurate and detailed information about the spatial distribution of the benefits provided by ES to the society. The spatial distribution of the flow of benefits supplied by ES provides important information to support the decision makers (i.e. planners and managers) in the definition and implementation of the landscape planning strategies in the different areas. Besides, the economic evaluation of ES can provide information to understand the worth of natural capital following the green accounting approach. In a first stage of the work, the main ecosystem goods and services supplied by forests and grasslands were evaluated from the economic point of view using the appropriate economic valuation methods. In the second stage, the values of ES were made spatially explicit using a Geographical Information System approach (in a Quantum-GIS environment) and taking into account the ecological characteristics of each ecosystem service. The proposed method was applied in a case study in Austria. The test region is the Leiblachtal in Vorarlberg, involved in the Recharge.green project (Alpine Space Programme), which is aiming at reconciling ecosystem services, biodiversity and soil functions with an increasing use of renewable energies (hydropower, solar, wind and wood biomass).

\section{Materials and methods}

\section{Study area}

The study area Leiblachtal $\left(47^{\circ} 33^{\prime} 21^{\prime \prime} \mathrm{N}, 9^{\circ}\right.$ $\left.45^{\prime} 11^{\prime \prime} \mathrm{E}\right)$ is located in the north-western part of Vorarlberg (Austria), near the border with Germany (Figure 1). Subdivided in five municipalities (Lochau, Hörbranz, Hohenweiler, Möggers and Eichenberg), the study area has a population of approximately 14,000 inhabitants and 5,200 households. The total area of the Leiblachtal $\left(51 \mathrm{~km}^{2}\right)$ consists of $48.9 \%$ forests $(2,497 \mathrm{ha}), 39.5 \%$ grasslands $(2,017 \mathrm{ha})$, $4.1 \%$ agricultural crops (208 ha) and $7.5 \%$ urban area (381 ha).

About forests, the main forest types are Norway spruce (Picea abies (L.) H. Karst), silver fir (Abies alba Mill.) and European beech ( $\mathrm{Fa}$ gus sylvatica L.) mixed forests $(75.3 \%)$, fol- 


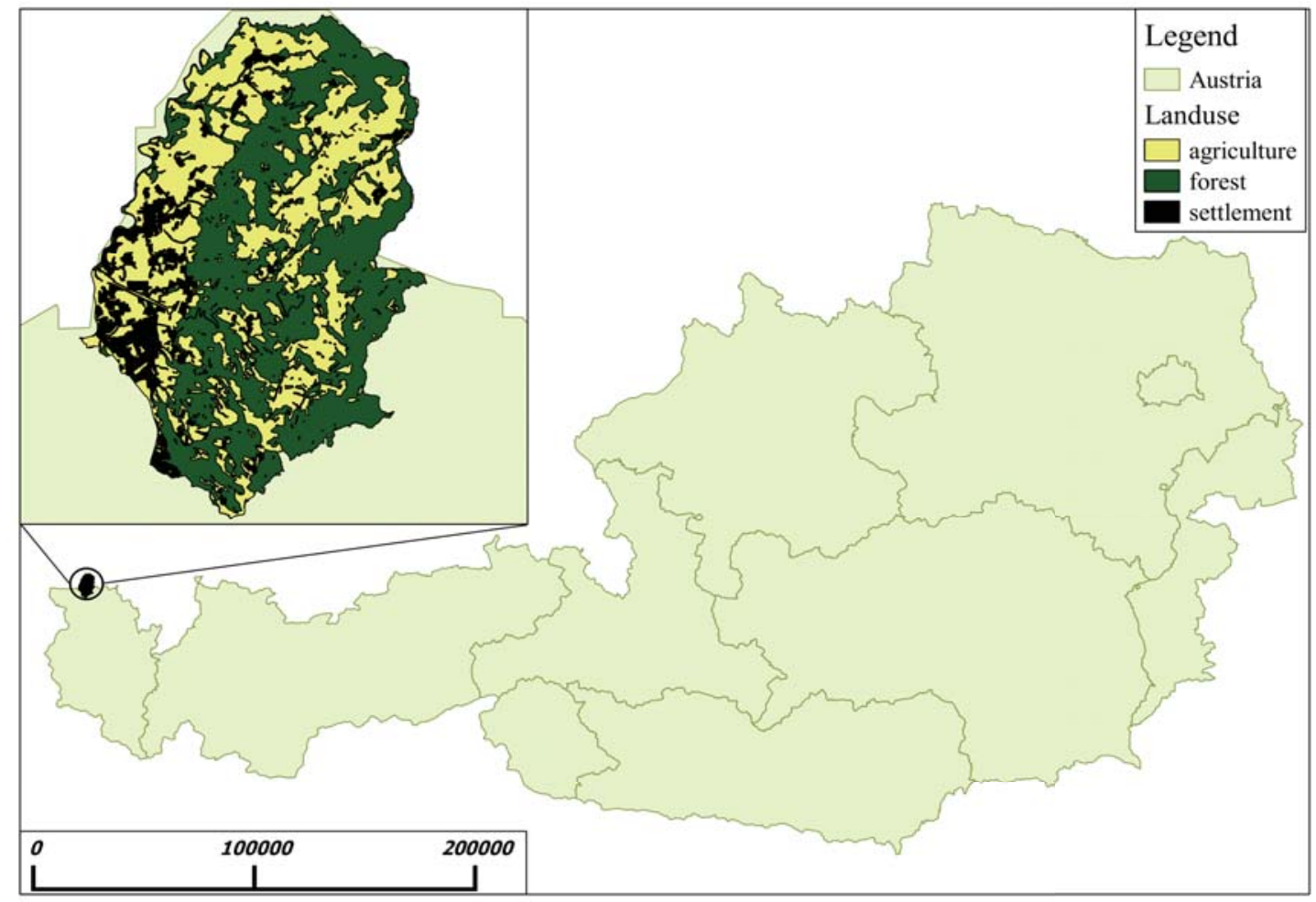

Figure 1 Location of study area (Leiblachtal) in Austria

lowed by pure Norway spruce forests (13.6\%) and the mixed broadleaves coppices (4.5\%). Considering the tree species composition, mixed forests cover 1,880 ha, pure conifer forests cover 429 ha, while pure broadleaves forests cover the remaining 188 ha which can be found in the lower valley area.

About grasslands, in the Leiblachtal there are 180 farms (23\% farms without livestock and $77 \%$ farms with livestock) for a total of around 3,700 cattle, 270 sheep and goats, 1,400 pigs, 80 horses and 4,300 chickens. Livestock Units (LUs) in the study area are 4,783 (Rücker 2013). Pasture areas are located at the highest altitude, while meadows and agricultural crops are near to urban areas in the low part of the valley.

The Leiblachtal area is characterized by forest and agricultural activities, followed by tourism which is focused on 580 thousand daily tourists per year (target period from March 2012 to March 2013) (Seidel et al. 2013). In particular, most part of the economic activities are in the Hörbranz and Lochau towns, while the small villages of Hohenweiler, Eichenberg and Möggers are rural areas characterized by a high importance of forestry and agriculture activities. Besides, many inhabitants commute to the nearby city of Bregenz and the Rhine Valley.

\section{Economic valuation approach}

In the international literature, many economic values related to the forest functions have been identified. The main distinction is between use values (direct and indirect use values) and non-use values (option and existence values). The direct-use values include value to the individuals (i.e. forest owners) who extract timber, fuelwood, berries, mushrooms and other forest products, while the indirect use-values are the benefits derived from ecosystem functions (i.e. soil conservation, avalanche and landslide prevention, water quality and purification). The non-use values refer to the willingness to pay 
to maintain some good in existence (Bateman et al. 2002). The latter category includes the option values - potential future use of the resource - and the existence values that include bequest, stewardship, and benevolence motives (Pak et al. 2010). Capturing these different values is possible using economic valuation methods.

In the present research, three categories of ES were evaluated from the economic point of view (provisioning, regulating and cultural services), while supporting services were not included in order to avoid double counting of value (Hein et al. 2006). The main benefits provided by forest and grassland ES were evaluated using different economic valuation methods (such as market price, replacement cost method and benefit transfer method) and the estimated benefits were made spatially explicit.

The ES considered in the analysis and the economic valuation methods used are in Table 1. The economic valuations of all benefits derived from ES have been made in reference to the year 2012. In particular, the provisioning services - timber, fuelwood, and non-wood forest products (direct consumptive uses) - were evaluated by market prices, while the cultural services - outdoor recreation (direct non-consumptive use) - were evaluated through the
Benefit Transfer (BT) method. Instead, the regulating services (indirect use-values) were evaluated using different economic valuation methods: the market price for the carbon storage and the replacement cost method for the protection against natural hazards.

Provisioning services. The provisioning services supplied by forests considered in the case study were: timber, fuelwood, non-wood forest products (NWFP).

In the Leiblachtal, the wood forest production is quite important for the local economy. The standing stock is $390 \mathrm{~m}^{3} / \mathrm{ha}$ with an annual increment equal to $12.5 \mathrm{~m}^{3} /$ ha year (Seidel et al. 2013). The annual harvesting rate is about $85 \%$ of annual increment $\left(10.7 \mathrm{~m}^{3} / \mathrm{ha}\right)$. The timber and fuelwood production were estimated considering the local market price and the harvested volume subdivided by forest types. In the study area, the annual wood production is about 26.5 million of $\mathrm{m}^{3}$ per year and around $60 \%$ of harvesting volume is commercial timber, while the remaining $40 \%$ is used for energy purpose (fuelwood). The average price of timber varies between 65 and $150 € / \mathrm{m}^{3}$ in consideration of the tree species and quality of wood (low, medium and high quality of wood), while the price of fuelwood is around $150 € / \mathrm{t}$ with small changes due to the calorific value of the tree species.

Table 1 Ecosystem goods and services and economic valuation methods used in the Leiblachtal study area

\begin{tabular}{|c|c|c|c|}
\hline \multicolumn{2}{|l|}{ Forests } & \multicolumn{2}{|l|}{ Grasslands } \\
\hline Provisioning services & & & \\
\hline Timber production & Market price & Hay production & Market price \\
\hline Fuelwood production & Market price & Livestock & Market price \\
\hline $\begin{array}{l}\text { NWFP (hunting products, berries } \\
\text { and mushrooms) }\end{array}$ & Market price & & \\
\hline \multicolumn{4}{|l|}{ Regulating services } \\
\hline $\begin{array}{l}\text { Protection against natural hazards } \\
\text { (direct and indirect protection) }\end{array}$ & $\begin{array}{l}\text { Replacement } \\
\text { cost method }\end{array}$ & $\begin{array}{l}\text { Protection against natural } \\
\text { hazards (indirect protection) }\end{array}$ & $\begin{array}{l}\text { Replacement cost } \\
\text { method }\end{array}$ \\
\hline $\begin{array}{l}\text { Carbon storage (living and non- } \\
\text { living forest biomass) }\end{array}$ & $\begin{array}{l}\text { Voluntary market } \\
\text { price }\end{array}$ & $\begin{array}{l}\text { Carbon storage in living } \\
\text { biomass }\end{array}$ & $\begin{array}{l}\text { Voluntary market } \\
\text { price }\end{array}$ \\
\hline \multicolumn{4}{|l|}{ Cultural services } \\
\hline $\begin{array}{l}\text { Outdoor recreation (hiking, } \\
\text { walking, picnicking, etc.) }\end{array}$ & $\begin{array}{l}\text { Benefit transfer } \\
\text { method }\end{array}$ & $\begin{array}{l}\text { Outdoor recreation (hiking, } \\
\text { walking, picnicking, etc.) }\end{array}$ & $\begin{array}{l}\text { Benefit transfer } \\
\text { method }\end{array}$ \\
\hline
\end{tabular}


NWFP were assessed considering the main products supplied by the Alpine forests: hunting products (meat, trophy and skin), berries (bilberries and raspberries) and mushrooms. The economic value of hunting products was calculated starting from the data of animals hunted (ungulates, other mammals and birds) in a target year (2012) in the Leiblachtal area. Three components were considered: meat for all comestible animals, skin for all ungulates, and trophy only for the male of ungulates (red deer, roe deer and chamois).

The quantity of berries and mushrooms collected were accounted taking into account the household in the study area (5,200 households), while the tourists (around 582,000 tourists) were excluded from this analysis because in the Leiblachtal this tourism activity is quite limited. The direct analysis of the importance of NWFP collection for inhabitants realized by Šišak (2006) in Czech Republic shows that the average annual amount of collected NWFP by householders is: mushrooms 5.36 $\mathrm{kg}$ /household, bilberries $2.61 \mathrm{~kg} /$ household, raspberries $1.00 \mathrm{~kg} /$ household. Besides, considering empirical data on outdoor activities by Wilhelmsen (2009) in Norway the amount of collected NWFP was calculated only for one third of the households. The economic values of these products were calculated multiplying these quantities for the local prices $(7.5 € / \mathrm{kg}$ for mushrooms, $10 € / \mathrm{kg}$ for both berries). The data assessed in another European countries were used because there are no specific data on the annual amount of collected NWFP by householders in Vorarlberg region. Moreover, the approach used in Czech Republic and in Norway are transferable because forest types, mushroom species and forest accessibility to the householders are similar to those in this case study.

The estimated provisioning services supplied by grasslands were: hay production in meadows and livestock in pasture areas. The economic value of hay production was evaluated considering the annual hay production (about 10,000 dry $\mathrm{kg} / \mathrm{ha}$ derived by $4-5$ cuts per year) and the local price of hay $(0.14 € /$ dry $\mathrm{kg}$ ). The value of livestock grazing in the pasture areas was estimated taking into account the Livestock Units (LUs) per hectare and an average price of $550 € /$ LUs.

Regulating services. The regulating services considered in this study are the protection against natural hazards and the carbon storage in the vegetation and deadwood. These two ES were evaluated both for forests and for grasslands.

Protection against natural hazards. The protection against natural hazards - such as soil erosion, landslides, rockfalls and avalanches (Dorren et al. 2004) - was estimated through the replacement cost approach (Freeman III 2003). This approach assesses the cost incurred by replacing forests and grasslands with artificial substitutes (Dixon et al. 1997). The artificial substitutes are chosen distinguishing between direct and indirect protection (Notaro \& Paletto 2012). According to the third Ministerial Conference for the Protection of Forests in Europe (Lisbon 1998), indirect protection can be defined as the prevention of soil erosion and regulation of water flow, while direct protection involves safeguarding human life and activities from natural risks (Motta \& Haudemand 2000, Notaro \& Paletto 2012). The replacement cost method has been used to estimate the protective function of forests and grasslands, using the prices of artificial substitutes of public engineering works in South Tyrol (year 2012), being a good proxy for the Vorarlberg area, where such a price list is not available. The total costs of carrying out and maintaining the different artificial substitutes - distinguishing for land use (forest and grassland) and type of protection (direct and indirect protection) - were taken into account to calculate an annual cost per unit area (hectare). In particular, the artificial substitutes chosen were: (1) seeding for the indirect protection provided by grasslands (lifetime of 15 years), 
(2) hydro-seeding ${ }^{1)}$ for the indirect protection provided by forests (lifetime of 15 years), and (3) a simple palisade for the direct protection provided by forests (lifetime of 35 years). The costs of simple palisades were estimated considering soil preparation, modelling of the slope, provision and storage of all materials (e.g. local larch wood with a diameter 12-20 $\mathrm{cm})$. According to the bio-engineering guidelines the total cost per hectare was calculated assuming a linear development of $50 \mathrm{~m}$ for a total number of 46 rows of simple palisade (spacing between rows of $2.5 \mathrm{~m}$ ). For the annual cost calculation, a conservative interest rate was chosen and fixed at $2 \%$, according to Freeman III's (2003) ranges. According to Notaro \& Paletto (2012) the annuity for each bio-engineering work was calculated using this formula:

$$
A=\frac{C \cdot r}{(1+r)^{t}}+M
$$

where $A$ - the annuity, $C$ - the total setting up costs $(€), r$ - the environmental discounting rate $(\%), t$ - the lifetime (number of years) and $M$ - the maintenance costs $(€)$.

Carbon storage. The procedure used to estimate the quantity of carbon stored in forests follows the For-Est approach (Federici et al. 2008), based on the IPCC "Good Practice Guidance for Land use, land-use Change and Forestry" (IPCC 2003). The annual forest capacity to transform atmospheric carbon into biomass was estimated considering three carbon pools: above-ground biomass, belowground biomass and deadwood. The other two carbon pools (litter and organic matter in the soil) were not considered as the changes in the annual increment of carbon stock are negligible.

\footnotetext{
1) Hydro-seeding is a planting process that uses a slurry of seed and mulch and which is applied in the slopes subject to soil erosion, while the simple palisade is a work of bioengineering in local larch wood (diameter 12-20 cm) and mixed grass used to cover the soil (Notaro \& Paletto 2012).
}

The formula used to estimate the economic value of carbon storage in living forest biomass (above-ground and below-ground biomass) is the following:

$V_{c}=[(I \cdot B E F \cdot W B D)+(I \cdot W B D \cdot R)] \cdot 0.5 \cdot 3.67 \cdot p_{C}$

where:

$V_{c}$ - value of carbon storage in above-ground and below-ground biomass $(€)$;

$I$ - annual volume increment $\left(\mathrm{m}^{3} /\right.$ ha year);

$B E F$ - biomass expansion factor (usually forest volume is referred to stem volume, and the expansion factor accounts for components such as branches, and leaves);

$W B D$ - wood basal density $\left(\mathrm{kg} / \mathrm{m}^{3}\right)$;

$R$ - roots/shoot ratio;

0.5 - coefficient of carbon content;

3.67 - coefficient from $\mathrm{C}$ to $\mathrm{CO}_{2}$

$p_{c}$ - carbon price of the voluntary carbon market $\left(€ / \mathrm{tCO}_{2}\right)$.

Additionally, the carbon storage in non-living forest biomass (standing dead trees and lying deadwood with a minimum diameter of $5.0 \mathrm{~cm}$ ) was quantified considering the data of the last Austrian National Forest Inventory (NFI17). The mean volume of deadwood in the Alpine regions of Austria is $23.8 \mathrm{~m}^{3} / \mathrm{ha}$ (around 51\% standing dead trees and 49\% lying deadwood), this value is highest than the mean national value that is around $20 \mathrm{~m}^{3} / \mathrm{ha}$ (BFW 2011). The volume data were used to calculate the carbon content through the values of basal density per decay class, tree species and component (i.e. standing dead trees and lying deadwood) by Di Cosmo et al. (2013), and the standard carbon factor equal to 0.5 (Coomes et al. 2002). Starting from these data of carbon stock, the economic fluxes in deadwood carbon pool were estimated taking into account the distribution of the volume per decay classes (using a five-classes system) and the decomposition time rate of each decay class (Degiampietro 2014).

The capacity of grasslands to act as net carbon sinks may result from the continuous 
turnover of biomass and stable storage of this organic matter in soil (Schulze et al. 2000). The amount of carbon stored in grasslands depends on climatic condition, site features and management strategies. Considering as key variable of carbon flux the management strategies, Rogiers et al. (2005) estimate for the entire growing season that the net carbon loss in the managed meadow is $79 \pm 17 \mathrm{~g} \mathrm{C} / \mathrm{m}^{2}$ and in the pasture $270 \pm 24 \mathrm{~g} \mathrm{C} / \mathrm{m}^{2}$. The economic evaluation of carbon storage in grasslands was conducted applying the voluntary carbon market price to these values of carbon fluxes.

The economic evaluation of carbon storage in grasslands was conducted applying the voluntary carbon market price to these carbon fluexs.

Cultural services.Cultural services supplied by forests can be defined as non-material benefits that people obtain from forests through spiritual enrichment, cognitive development, recreation and aesthetic experience (Maes et al. 2012). In the present study, we focused on the outdoor recreation in mountain areas such as hiking, walking, picnicking, jogging and landscape viewing. The outdoor recreation was evaluated using the Benefit Transfer (BT) method. BT method consists in examining the results of surveys undertaken in specific contexts ("study site") and transferring them to similar unstudied situations of interest for policy making defined "policy site" (Bergstrom \& De Civita 1999, Wilson \& Hoehn 2006). BT method is a well-developed method in USA and Canada to value an environmental good or service in cases in which the resources needed to obtain primary data are missing. Subsequently, this method is becoming popular in Europe because it is a good alternative to field surveys. Primary studies are expensive, in terms of both money and time, and their implementation is not always feasible. BT method is a cost-effective approach in case of budget constraints, time limitations and resource impacts that are expected to be low (Rosenberger \& Loomis 2001). However, the estimates are necessarily less accurate, so that it is regarded as a "second best" strategy (Bartczak et al. 2008). The economic value estimated in the "study site" can be transferred to the "policy site" either as monetary units (value transfers) or as a function (function transfers) that defines the attributes of an ecological and economic choice setting (Loomis 2005). Value transfers can be applied considering a single benefit estimate from a specific study site, or a measure of central tendency for several benefit estimates in many study sites. While the function transfers consider the transfer of a demand function from a study site, or a meta regression analysis function derived from several study sites (Rosenberger \& Loomis 2001). In this research, we used the average value transfer method, considering the previous studies related to the recreation in mountain forests in Europe. The accuracy of this method depends on the errors contained in the original studies, part of which could be transferred when the BT method is applied. In order to limit the transfer of this error, outdoor recreation was estimated through a literature analysis focused on the outdoor activities in forests (i.e. hiking, walking, picnicking, jogging and landscape viewing). This analysis collected 28 papers published between 1977 and 2012 (Grilli et al. 2014). The meta-analysis includes only European mountain forests as study sites, motivated by the necessity to compare values related to sites with similar altitude, forest tree composition and touristic target, in compliance with the prescriptions made by Boyle and Bergstrom (1992). The economic values of outdoor recreation were estimated and transferred distinguishing between two variables: forest types (mixed forests, pure conifer forests and pure broadleaves forests) and altitude (above and below 1,000 $\mathrm{m}$ a.s.1.). These variables were considered because they are related to the tourist attractiveness of an area (Paletto et al. 2013). Consequently, the average values were calculated for the following types of forests: mixed forests below (number of study 
sites $=5$ ) and above 1,000 $\mathrm{m}$ a.s.l. (number of study sites $=6$ ); pure broadleaves forests below (number of study sites $=6$ ) and above $1,000 \mathrm{~m}$ a.s.l. (number of study sites $=2$ ); pure conifer forests below (number of study sites $=3$ ) and above 1,000 $\mathrm{m}$ a.s.1. (number of study sites $=6$ ). Such a distinction is useful in order to achieve differences in the spatial location of the recreational value taking into account the tourist attractiveness of an area.

Due to the high variability of the years of the studies collected (from 1977 to 2012), the monetary quantities of the past years were actualized to 2012, before calculating the average value to be transferred, through a social interest rate of $1 \%$. The formula for discounting is:

$$
V_{p}=\sum_{i=0}^{n} V_{i t 0}(1+r)^{t}
$$

where $V_{p}$ is the current value in 2012, $V_{i t 0}$ is the value of the 1 -th site estimated in the year of the study, $r$ is the social rate of discount and $t$ represent the number of years.

Also the outdoor recreation in grasslands was estimated using the method of average value transfer considering other studies realized in Europe (Notaro et al. 2008, Hönigová et al. 2012).

\section{Spatial approach}

The economic values of the benefits provided by ES were made spatially explicit taking into account the ecological characteristics of each ecosystem service and using a Geographical Information System approach (QuantumGIS). Thereby we aim at reproducing causal relationships between primary and secondary environmental variables and specific ES. The methodological framework used for mapping ES is shown in Figure 2. A set of thematic layers representing key variables was used. The layers were overlapped to analyse the spatial distribution of ES benefits. The used key variables were: (1) land uses, distinguishing among forests, pastures, meadows, agricultural crops and settlements; (2) forest types, distinguishing among pure conifer forests, pure broadleaved forests and mixed forests; (3) altitude, distinguishing between areas above and below 1,000 m a.s.1.; (4) forest tracks and paths network; (5) hydrographic network (rivers and streams); (6) type of forest protection (direct or indirect protection).

The map of land uses was used to distinguish the areas to be evaluated (forests and grasslands) from others (urban areas and agricultural crops). Also according with the categorization of ES shown in Table 1 (provisioning, regulating and cultural services), thematic layers were combined by using an overlay procedure. The resulting map is characterized by a number of polygons which express the values of the ES supply.

Regarding the provisioning services, the spatial distribution of timber and fuelwood was accounted considering the different forest types. For hunting products and mushrooms the values were assigned to all forest area, while bilberries and raspberries values were attributed only to the forest types with $\mathrm{Vac}$ cinium myrtillus (L.) and Rubus idaeus (L.) in the shrub layer. The provisioning services provided by grasslands were distinguished between meadows (hay production) and pasture (livestock).

Regarding to the regulating services, the carbon storage was mapped considering the difference among forest types. The value of indirect protection against natural hazards was assigned to the buffer of the rivers and streams (indirect protection), while the value of the landslides protection was attributed only to the direct protective forests. According to Hawes and Smith (2005) a buffer of the river width $30 \mathrm{~m}$ was used (15 $\mathrm{m}$ for side). The value of carbon storage in grasslands was assigned distinguishing between pastures and meadows.

Regarding to the cultural services, according to Casado-Arzuaga et al. (2014) the value of outdoor recreation was mapped taking into 


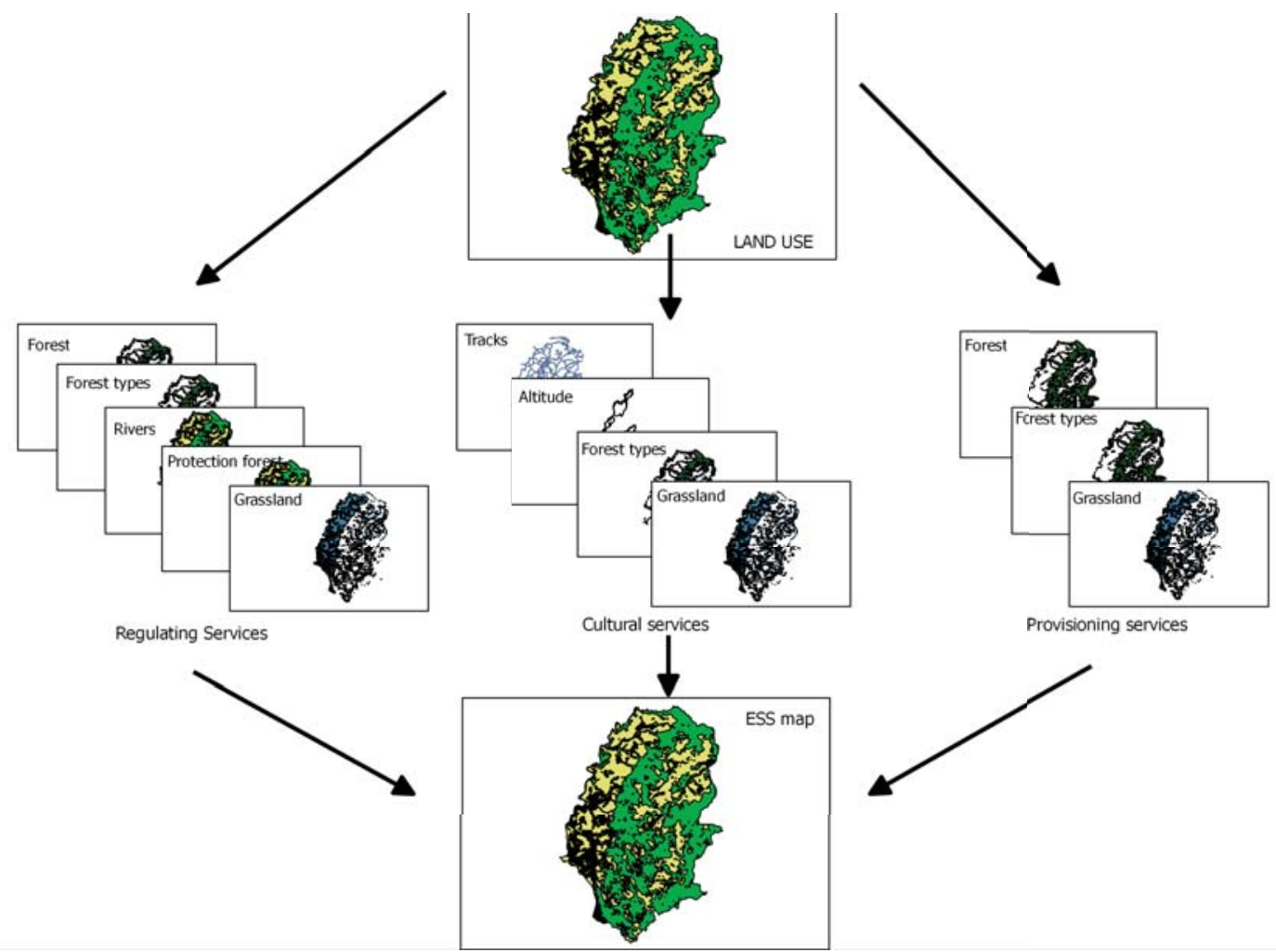

Figure 2 Graphical representation of the methodological framework to map the spatial distribution of ES

account two main components: the recreation potential and the recreation opportunity. The recreation potential is strictly linked to the territorial features associated with attractiveness for forest recreational activities. In this paper - according to Paletto et al. (2013) - two key variables have been used to assess the recreation potential: forest type and altitude (above and below 1,000 $\mathrm{m}$ a.s.1.). The recreation opportunity considers the infrastructure that was in place to host or guide the visitors such as forest tracks and paths network. Consequently, the value attributed to each individual forest polygon is the compromise between recreation potential and recreation opportunity. Moreover, the forest areas with a high recreational value were identified using a topographical map by 19 local stakeholders. Local stakeholders were identified considering their expertise and knowledge of local context. Consequently, the outdoor recreational values derived by meta-analysis have been applied only in the areas with high recreational values following the statements made by stakeholders. The value 166 of outdoor recreation in grasslands was calculated assuming a constant value for the whole area.

\section{Results and discussion}

\section{Economic values of ES}

Provisioning services. Timber, fuelwood and NWFP. The valuation of the ES supplied by forests shows that the provisioning services (timber, fuelwood and NWFP) have a high economic importance in Leiblachtal study area. The annual gross value of timber production was estimated in $423 € /$ ha year for mixed forests and in $118 € /$ ha year for the pure conifer forests. The gross value of fuelwood production was $231 € /$ ha year in mixed forests, $49 € /$ ha year in pure conifer forests, and $62 € /$ ha year in pure broadleaves forests. The quite high gross values of wood production in Leiblachtal study area are due to the high harvesting rate ( $85 \%$ of the annual increment) 
and the discrete quality of wood. Regarding to the differences among forest types, several studies confirm that the mixed forests are more productive than pure forests because there is a positive relationship between tree stand diversity and wood production (Caspersen \& Pacala 2001, Paquette \& Messier 2011).

Taking into account the average harvest costs including labour (20-25 €/ $\mathrm{m}^{3}$ depending on tree species and site conditions - Seidl et al. 2007), the net value of wood production is little more than three-quarters of the gross value (around $380 € /$ ha year timber and $240 € /$ ha year fuelwood).

The annual value of NWFP was estimated in $101 € /$ ha year, while the total value for Leiblachtal study area is around 252 thousand $€$. In particular, the total annual amount of mushrooms collected by householders in Leiblachtal is $11,150 \mathrm{~kg}$ for an economic value of $33.5 € /$ ha year; this value is comparable with those reported by Martínez de Aragón et al. (2011) in Catalonia. The total annual quantity of berries collected by householders is $5,430 \mathrm{~kg}$ of bilberries and 2,080 kg of raspberries. Starting from these data, the potential economic value of bilberries is $21.7 € /$ ha year and of raspberries is $8.3 € /$ ha year.

The total value of hunting products is $37.5 € /$ ha year $(93,488 €$ per year) of which $51 \%$ corresponds meat, 44\% corresponds trophy and $5 \%$ corresponds skin (Table 2 ). This value is quite low in comparison to the values of berries and mushrooms. Other studies in Europe show values of hunting products between 5 $€ /$ ha year and $10 € /$ ha year (Goio et al. 2008, Hein 2011).

Hay production and livestock. Considering the number of cuts per year and the average cut hay production, the total value of this category of provisioning service is $232,764 €$ per year $(1,400 € /$ ha of grasslands year). The gross yield of hay production in Leiblachtal study area has a high value if compared with the other ecosystem goods and services. Fontana et al. (2013) estimated a gross yield of $1,080 € /$ ha year in a study area with similar environmental and socio-economic characteristics (South Tyrol, Italy). Taking into account the labour and mechanization costs estimable in $1,200 € /$ ha the net yield of hay production is $200 € /$ ha year.

Finally, the gross value of livestock in Leiblachtal study area is $1,094,748 €$ per year (453 $€ /$ ha of grasslands per year). In the present analysis, the main components of livestock are the cows $(844,139 €$ per year) and pigs $(163,083$ $€ /$ per year) as reported in Table 3.

Regulating services.Protection against natural hazards. In literature, the forests protection against natural hazard is considered the most important ES in mountain areas both from an ecological and economic point of view (Merlo \& Rojas Briales 2000). The results of the present study confirm the high level of importance of this forest function (Table 4), in particular a value of $581 € /$ ha per year for the indirect protection forests and a value of 707 $€ /$ ha year for the direct protection forests were estimated. The economic value of grasslands protection against hydrogeological hazards is $213 € /$ ha year.

It is important to highlight that the economic values of hydrogeological protection of Alpine forests evidenced in other studies are comparable to the results of the present study. In fact, Goio et al. (2008) showed an average value of 212.2 $€$ /ha year for the entire Province of Trento, while Notaro and Paletto (2012) in a small scale forest (Valdastico forest) evidenced a value of $284.2 € /$ ha year for the hydrogeological protection function. Finally, we point out that the evaluation of this ES is deeply influenced by the economic valuation method used.

Carbon storage. The results show that the amount of carbon storage in living forest biomass is $3.75 \mathrm{tC} /$ ha year $(3.13 \mathrm{tC} / \mathrm{ha}$ for aboveground biomass and $0.63 \mathrm{tC} / \mathrm{ha}$ for belowground biomass) corresponding to an average value of $21.1 € /$ ha year. This average value is strongly influenced by forest types as evidenced in Table 5. The mixed forests composed by Norway spruce, silver fir and European beech have annual increment significantly higher 
Table 2 Total annual value of hunting products in Leiblachtal study area

\begin{tabular}{|c|c|c|c|c|c|}
\hline Hunting species & $\begin{array}{l}\mathrm{N}^{\circ} \\
\text { animals }\end{array}$ & $\begin{array}{l}\text { Value of meat } \\
(€ / \text { ha year })\end{array}$ & $\begin{array}{l}\text { Value of trophy } \\
(€ / \text { ha year) }\end{array}$ & $\begin{array}{l}\text { Value of skin } \\
(€ / \text { ha year })\end{array}$ & $\begin{array}{l}\text { Total value } \\
(€)\end{array}$ \\
\hline $\begin{array}{l}\text { Red deer (male and } \\
\text { female) }\end{array}$ & 370 & 20,820 & 2,550 & 319 & 23,689 \\
\hline $\begin{array}{l}\text { Roe deer (male and } \\
\text { female) }\end{array}$ & 70 & 22,547 & 37,386 & 3,739 & 63,672 \\
\hline $\begin{array}{l}\text { Chamois (male and } \\
\text { female) }\end{array}$ & 95 & 3,612 & 1,477 & 591 & 5,680 \\
\hline Wild boar & 1 & 168 & - & & 168 \\
\hline Black grouse & 1 & 12.5 & - & & 12.5 \\
\hline Pheasants & 7 & 51.9 & - & & 51.9 \\
\hline Wild pigeons & 6 & 14.0 & - & & 14.0 \\
\hline Wild ducks & 24 & 181.5 & - & & 181.5 \\
\hline Coots & 3 & 20.3 & - & & 20.3 \\
\hline Total value (€/ha) & & 47,427 & 41,413 & 4,648 & 93,488 \\
\hline $\begin{array}{l}\text { Total value ( } € / \text { ha } \\
\text { year) }\end{array}$ & & 19.0 & 16.6 & 1.9 & 37.5 \\
\hline
\end{tabular}

Table 3 Number of farms, number of animals, LUs and value of livestock in Leiblachtal study area

\begin{tabular}{|c|c|c|c|c|c|c|c|c|}
\hline Municipality & $\begin{array}{l}\text { Farms without } \\
\text { livestock grazing }\end{array}$ & $\begin{array}{l}\text { Farms with } \\
\text { livestock grazing }\end{array}$ & Horses & Pigs & Sheeps & Goats & Chicken & Cow \\
\hline Eichenberg & 6 & 33 & 13 & 70 & 19 & 24 & 355 & 630 \\
\hline Hörbranz & 10 & 23 & 30 & 205 & 12 & 62 & 353 & 909 \\
\hline Hohenweiler & 9 & 22 & 2 & 929 & 8 & 2 & 775 & 733 \\
\hline Lochau & 7 & 28 & 17 & 9 & 103 & 8 & 239 & 306 \\
\hline Möggers & 10 & 32 & 21 & 212 & 4 & 24 & 2650 & 1110 \\
\hline Total & 42 & 138 & 83 & 1425 & 146 & 120 & 4372 & 3688 \\
\hline LUs & & & 49.8 & 712.5 & 14.6 & 12 & 306 & 3688 \\
\hline $\begin{array}{l}\text { Value }(€ / \\
\text { year })\end{array}$ & & & 11,399 & 163,083 & 3,341 & 2,747 & 70,040 & 844,139 \\
\hline
\end{tabular}

Note. Source: modified by http://www.vorarlberg.at/pdf/agrarstrukturerhebung2014.pdf.

than the other forest types (pure conifer and pure broadleaves forests). Consequently, the value of mixed forests is about $50.0 € /$ ha year, while for the pure conifer forests the value is $11.5 € /$ ha year and for the pure broadleaves forests is $6.5 € /$ ha year. The average value of this forest ecosystem service evaluated in the present work is similar to those estimated in other European case studies that showed values for the above-ground biomass included in a range between 6 and $40 € /$ ha year (Goio et al. 2008, Hein 2011, Šišak 2013). In addition, a Spanish study that explored the populations' willingness to pay (WTP) for the afforestation of marginal agricultural lands to reduce the carbon dioxide in the atmosphere shows a value between $0.0004 €$ and $0.025 €$ per $\mathrm{tCO}_{2}$ per person and year (Mavsar et al. 2014).

The annual economic value of carbon storage in the grasslands is negative in the managed areas: $-1.3 € /$ ha year for the meadows and $-4.6 € /$ ha year for the pastures. In the grasslands the intensity of management has a negative relationships with the carbon storage, the 
Table 4 Economic values of protection against natural hazards by forests and grasslands in Leiblachtal study area

\begin{tabular}{llclll}
\hline Land use/protection & Artificial substitute & $\begin{array}{l}\text { Unit costs } \\
\left(€ / \mathrm{m}^{2}\right)\end{array}$ & $\begin{array}{l}\text { Value } \\
(€ / \text { ha year })\end{array}$ & $\begin{array}{l}\text { Surface } \\
(\text { ha })\end{array}$ & $\begin{array}{l}\text { Total value } \\
(€ \text { per year })\end{array}$ \\
\hline Grasslands & Seeding & 1.43 & 213 & 2017 & 428,613 \\
Indirect protection forests & Hydro-seeding & 3.91 & 581 & 5.7 & 3312 \\
$\begin{array}{l}\text { Direct protection forests } \\
\text { Total }\end{array}$ & Simple palisade & 34.0 & 707 & 986 & 697,102 \\
\hline
\end{tabular}

Table 5 Values of carbon storage by land use and land cover in Leiblachtal study area

\begin{tabular}{llc}
\hline Land use and land cover & Ecosystem components considered & Value (€/ha year) \\
\hline \multirow{3}{*}{ Mixed forests } & Above-ground biomass & 40.4 \\
& Below-ground biomass & 7.9 \\
& Non-living biomass & 1.6 \\
\hline \multirow{3}{*}{ Pure conifer forests } & Above-ground biomass & 8.1 \\
& Below-ground biomass & 1.8 \\
& Non-living biomass & 1.6 \\
\hline \multirow{2}{*}{ Pure broadleaves forests } & Above-ground biomass & 4.1 \\
& Below-ground biomass & 0.8 \\
\hline Managed meadows & Non-living biomass & 1.6 \\
\hline Pastures & Living biomass & -1.3 \\
\hline
\end{tabular}

more the management practices are intensive, the more the carbon balance is negative. In the Leiblachtal study area, the total economic balance of carbon storage (forests and grasslands) is $63.2 € /$ ha year.

It is important to highlight that the values of this ecosystem service are strongly affected by the changes in the carbon market price. According to the State of the Voluntary Carbon Markets (2014) the average voluntary carbon price decreases from $7.3 \$ / \mathrm{tCO}_{2}$ to $4.9 \$ / \mathrm{tCO}_{2}$ in the period 2008-2013 (Peters-Stanley \& Gloria Gonzalez 2014). Similarly, the average carbon price of the Emission Trading Scheme of the European Union (UE-ETS) fluctuated between $6 € / \mathrm{tCO}_{2}$ and $9 € / \mathrm{tCO}_{2}$ (period 20082012).

Cultural services. The results of the metaanalysis for outdoor recreation show interesting differences due to the landscape pattern characteristics. The mean recreational value obtained is $10.57 €$ per visit per person in mountain forest areas. If compared to flat areas, mountain forests seems to be more valuable for tourists. Zandersen (2008), applying a meta-analysis for recreation in forests in the European northern countries, collected a database of recreational values for forests mostly located in flat areas, obtaining much lower mean values. When applying the BT, it can be noticed that the total value of outdoor recreation in forests is, globally, about 84.5 thousand $€$ (on average 33.8 $€ /$ ha year), while the total value of outdoor recreation in grasslands is about 109 thousand $€$ (on average $54.1 € /$ ha year). The preferences of tourists for the open areas and the related higher willingness to pay is confirmed from other studies (Notaro \& Paletto 2011). Besides, we investigated the benefits provided by different forest type and altitude. Based on the characteristics of the study area considered in the meta-analysis, we calculated the value of 
mixed, conifer and broadleaves forests separately. This further analysis showed a high value for mixed forests (39.7 €/ha year) compared to the other forest types: pure conifer forests (18.2 €/ha year) and pure broadleaves forests $(10.1 € /$ ha year). Tourists' preference for mixed forests is confirmed in the literature, not only in WTP studies but also in qualitative works (Paletto et al. 2013) investigating visitors' preferences for forest landscape. Table 6 summarizes the values of outdoor recreation subdivided per forest type (mixed forests, pure conifer forests, and pure broadleaves forests) and altitude (above and below 1,000 m).

The average value of this study is relatively higher than the values estimated in Austria for the Grosser Ahornboden using the Travel Cost method (Glück \& Kuen 1977). Nevertheless, other studies in Europe evaluated the outdoor recreation in forests in a wide range of values from $0.66 €$ to $112 €$ per visit (Goio et al. 2008, Bartczak et al. 2008, Zandersen \& Tol 2009, Voces González et al. 2010). This high variability is among other factors linked to the economic valuation methods used (i.e. contingent valuation, travel cost method, choice experiment), the distance to urban areas and/or recreational areas, the socio-economic characteristics of tourists (cultural differences).

\section{Spatial distribution of benefits provided by ES}

The spatial analysis of the results for category of ecosystem service shows that the highest values are for the provisioning services supplied by forests in a range between around
$200 € /$ ha year and 1,400 €/ha year (Figure 3). Grasslands are differentiated into two classes, depending on management. In particular, the productive forests and the managed meadows close to urban areas have the highest values, while the lowest values are found in the high mountain areas. These differences are mainly related to site productivity and to the different type of management.

The spatial location of regulating services values are in Figure 4, for this category of ES the values are distributed in a range between $10 € /$ ha year and $760 € /$ ha year. The zones with near-zero values are meadows and pastures with a minor role with regard to the protection against natural hazards, while the highest values are found for the protective forests close to the settlements (direct protection).

The cultural services have low values when compared to the other two categories, the range vary from $5 € /$ ha year to $60 € /$ ha year (Figure 5). These differences are due to the site characteristics (i.e. open areas or closed forests) and the geographical location (distance from roads and settlements).

\section{Conclusions}

The integration of economic values of different goods and services supplied by natural ecosystems in the decision making process is a relevant issue in the political agenda. In the last decades, after the article "The value of the world's ES and natural capital" (Costanza et al. 1997), the literature on the economic valu-

Table 6 Values of outdoor recreation by forest type and altitude

\begin{tabular}{lll}
\hline Forest type & Altitude & Value (€/ha year) \\
\hline \multirow{2}{*}{ Mixed forests } & $<1,000 \mathrm{~m}$ & 42.9 \\
& $>1,000 \mathrm{~m}$ & 13.4 \\
\hline \multirow{2}{*}{ Pure conifer forests } & $<1,000 \mathrm{~m}$ & 15.7 \\
\hline \multirow{2}{*}{ Pure broadleaves forests } & $>1,000 \mathrm{~m}$ & 18.6 \\
\hline Grasslands & $<1,000 \mathrm{~m}$ & 9.1 \\
\hline
\end{tabular}

Note. Source: our elaboration starting from Grilli et al. (2014). 
ation of ES has increased. Despite this growing interest, the uncertainty about the benefits provided by ES and the spatial localization of these benefits is still high. Consequently, new studies focused on the spatial valuation of nonmarketed ES have a particular importance in
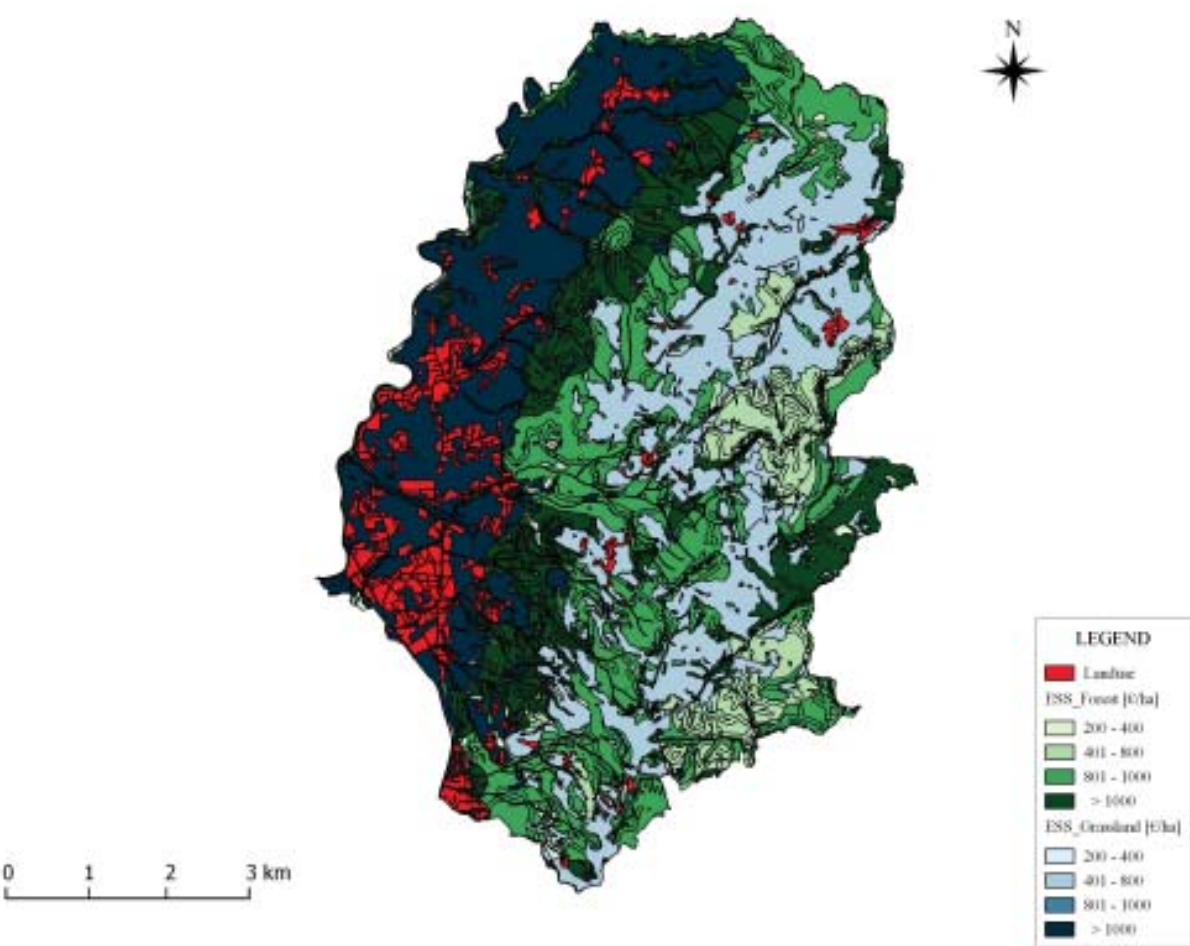

Figure 3 Spatial location of provisioning benefits in the Leiblachtal study area

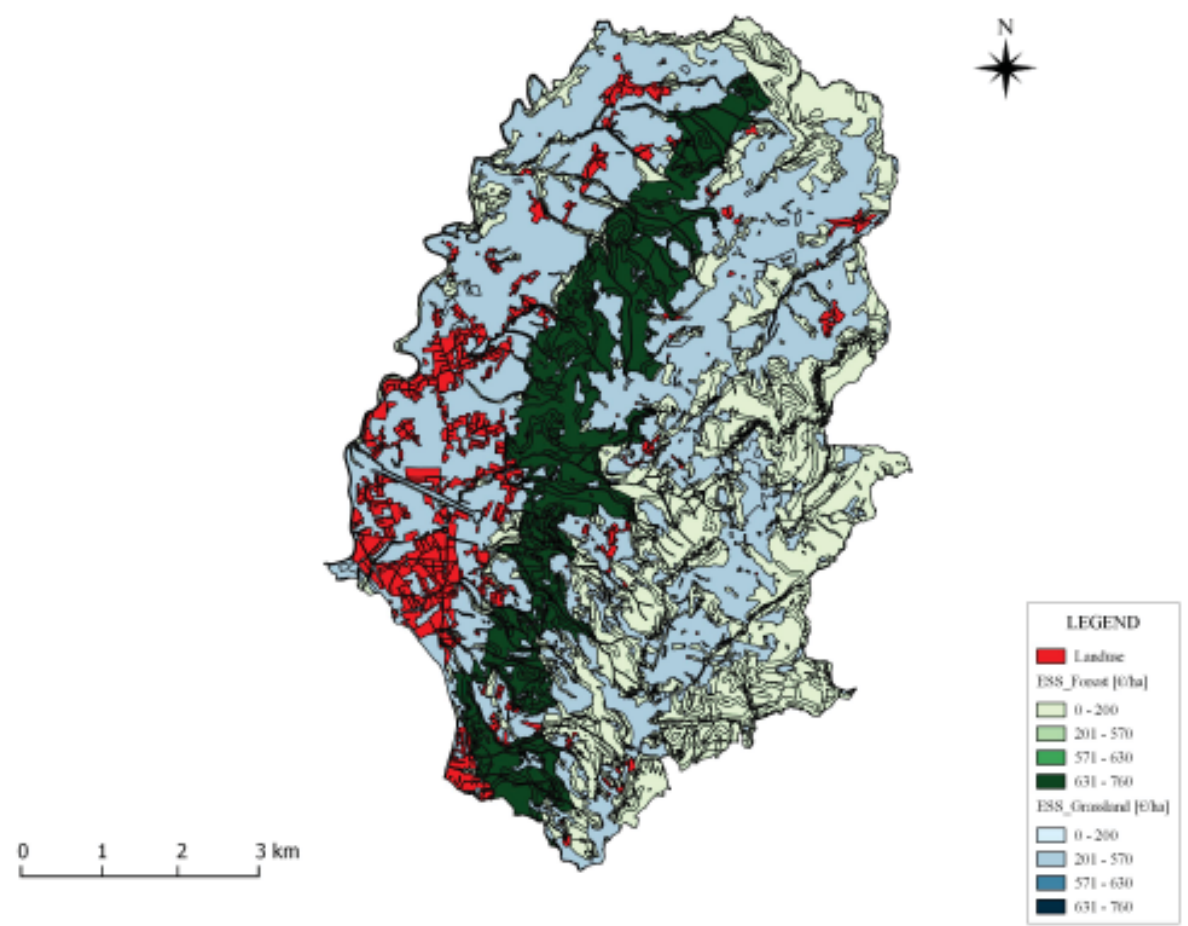

Figure 4 Spatial location of regulating services benefits in the Leiblachtal study area 


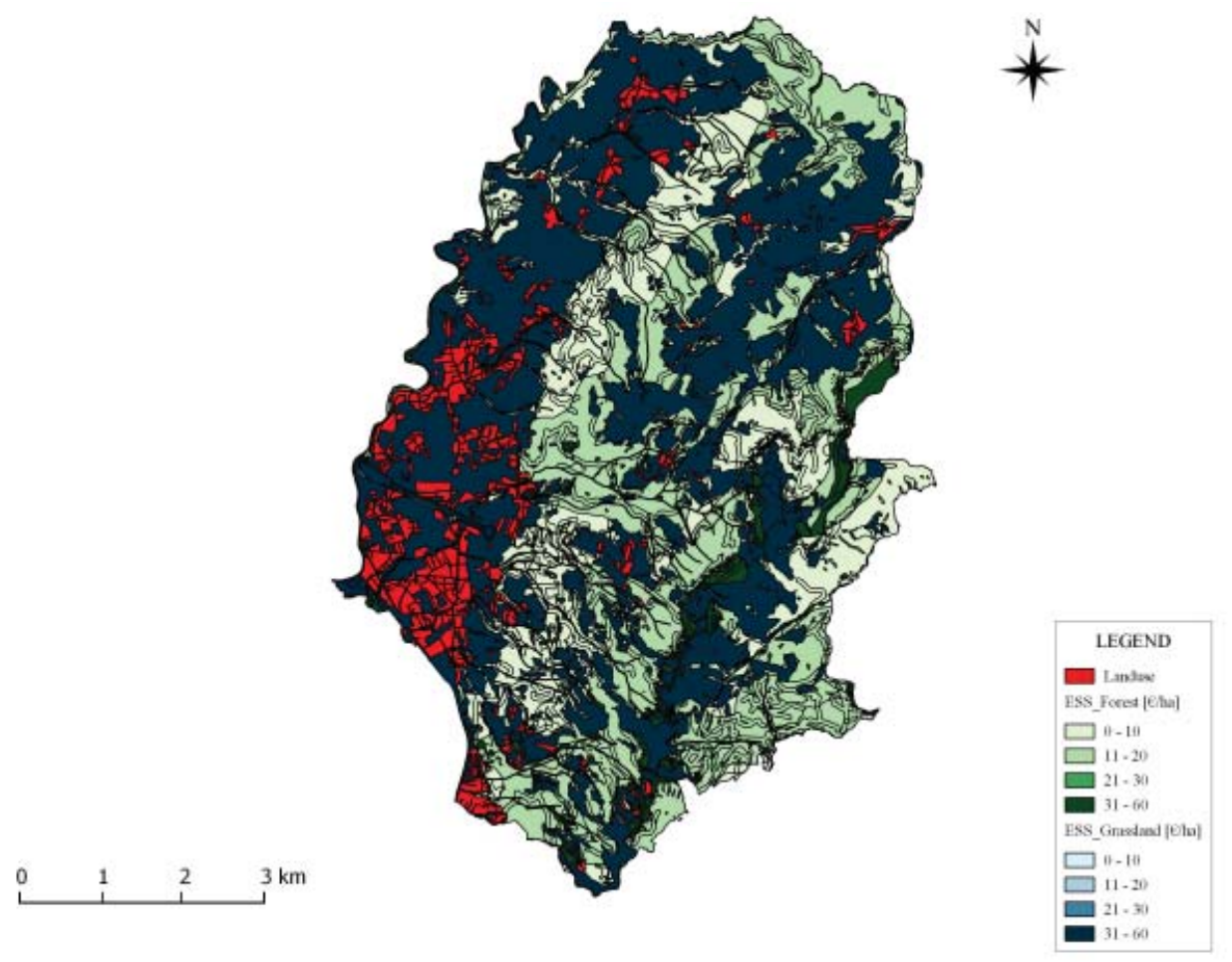

Figure 5 Spatial location of cultural services benefits in the Leiblachtal study area

order to increase the knowledge and information useful for the decision makers (i.e. policy makers, planners and managers). In particular, the spatial location of ES benefits estimated using standardized economic valuation methods is the key-point in order to provide credible and usable information. These information could support decision makers to understand which areas are the most attractive for tourism and with a greater value. Consequently, decision makers may adopt different management strategies for enhancing this forest function. The BT method, instead, was applied in order to evaluate the non-market benefit of recreation in natural areas. Although the method is widely applied, the quality of the data are lower than those of primary studies, so the figures should be accurately examined. As Brookshire and Neill (1992) pointed out, the level of accuracy of BT is at the most equal to the original survey. The studies collected in the meta-analysis have very similar features to Leiblachtal, so the results appear to be reliable. Anyway, the possible distortions in the assessment should be taken into consideration while implementing the values in a policy making process. The quality of information in the planning zones is particularly relevant at regional or local scales. Within the context of the Recharge.green project, the discussed spatial information will be essential for a correct siting of the renewable energy. Renewable energy development is important for reducing greenhouse gas (GHG) emissions but, on the other hand, renewable energies can cause damages on the environment and reduce the stock of natural resources. Understanding the values of the ecosystems allows decision makers to know the most important areas for conservation that should be untouched in order not to lose the ecosystem value. At the same time, the places where harvesting renewable energies is more effective from the ecological point of view. The damages connected with the anthropic pressure may be limited if such pressure is enhanced in the places where the ES values most likely to be depleted is already low, the spatial analysis is particularly keen for this purpose. 
The strengths of the proposed method are the simplicity of the methods used to assess the individual ES, the limited number of data for the spatial location of ES, and the ease of replicability of the method in other contexts.

The weakness point of the proposed method are typical of all economic valuations, such as the high variability among the ES benefits derived from the different studies. This variability is due to the characteristics of the sites and the economic valuation methods used. Therefore, it is appropriate in cases of landscape planning evaluate the ES at local scales considering closest literature values.

\section{Acknowledgements}

This work was done in the framework of the EU Recharge.green project (http://www.recharge-green.eu/it/). The authors would like to thank the partners in the Vorarlberg pilot region and in particular Mag. Dipl.-Ing. Markus Berchtold.

\section{References}

Adamowicz W., Boxall P., Williams M., Louviere J., 1998. Stated preference approaches for measuring passive use values: Choice experiments and contingent valuation. American Journal of Agricultural Economics 80(1): 6475. DOI: $10.2307 / 3180269$.

Bartczak A., Lindhjem H., Stenger A., 2008. Review of benefit transfer studies in the forest context. Scandinavian Journal of Forest Research 42: 276-304.

Bateman I.J., Carson R.T., Day B., Hanemann W.M., Hanley N., Hett T., Jones-Lee M., Loomes G., Mourato S., Özdemiroğlu E., Pearce D.W., Sugden R., Swanson J., 2002. Economic valuation with stated preference techniques: A manual. Edward Elgar Publishing, Cheltenham. DOI: $10.4337 / 9781781009727$.

Bergstrom J.C., De Civita P., 1999. Status of benefits transfer in the United States and Canada: a review. Canadian Journal of Agricultural Economics 47(1): 79-87. DOI: 10.1111/ j.1744-7976.1999.tb00218.x.

BFW, 2011. Bundesforschungs- und Ausbildungszentrum für Wald, Naturgefahren und Landschaft, Waldinventur 2007/09 (NFI7) [Federal research and training centre for forests, natural hazards and landscape, forest inventory 2007/09 (NFI7)], Praxis Information nr. 24-2011.

Boyle K.J., Bergstrom J.C., 1992. Benefit transfer studies: myths, pragmatism, and idealism. Water Resources Research 28(3): 657-663. DOI: 10.1029/91WR02591.

Brookshire D.S., Neill, H.R., 1992. Benefit transfers - conceptual and empirical issues. Water Resources Research 28(3): 651-655. DOI: 10.1029/91WR02590.

Busch M., La Notte A., Laporte V., Erhard M., 2012. Potentials of quantitative and qualitative approaches to assessing ecosystem services. Ecological Indicators 21: 89-103. DOI: 10.1016/ j.ecolind.2011.11.010.

Casado-Arzuaga I., Onaindia M., Madariaga I., Verburg P.H., 2014. Mapping recreation and aesthetic value of ecosystems in the Bilbao Metropolitan Greenbelt (northern Spain) to support landscape planning. Landscape Ecology 29: 1759-1770. DOI: 10.1007/s10980013-9945-2.

Caspersen J.P., Pacala S.W., 2001. Successional diversity and forest ecosystem function. Ecological Research 16: 895-903. DOI: 10.1046/j.1440-1703.2001.00455.x.

Coomes D.A., Allen R.B., Sčoty N.A., Goulding C., Beets P., 2002. Designing systems to monitor carbon stocks in forests and shrublands. Forest Ecology and Management 164: 89-108. DOI: 10.1016/S0378-1127(01)00592-8.

Costanza R., d'Arge R., de Groot R., Farber S. et al., 1997. The value of the world's ecosystem services and natural capital. Nature 387: 253-260. DOI: 10.1038/387253a0.

Daily G., 1997. Nature's Services: Societal Dependence on Natural Ecosystems. Island Press, Washington.

De Groot R., Alkemade R., Braat L., Hein L., Willemen L., 2010. Challenges in integrating the concept of ecosystem services and values in landscape planning, management and decision making. Ecological Complexity 7: 260-272. DOI: 10.1016/j.ecocom.2009.10.006.

Degiampietro P., 2014. Una valutazione economica della funzione di stoccaggio carbonio da parte del legno morto nelle regioni dell'Arco Alpino [Economic valuation of carbon stocking of the deadwood in Alpine forests]. Master thesis. University of Trento, Trento.

Di Cosmo L., Gasparini P., Paletto A., Nocetti M., 2013. Deadwood basic density values for national-level carbon stock estimates in Italy. Forest Ecology and Management 295: 51-58. DOI: 10.1016/j.foreco.2013.01.010.

Dixon J.A., Scura L.F., Carpenter R.A., Sherman P.B., 1997. Economic analysis of environmental impacts. Earthscan Publications, London, UK, 210 p.

Dorren L.K.A., Berger F., Imeson A.C., Maier B., Rey F., 2004. Integrity, stability and management of protection forests in the European Alps. Forest Ecology and Management 195: 165-176. DOI: 10.1016/ j.foreco.2004.02.057

Eade D.O.E., Moran D., 1996. Spatial economic valuation: benefit transfer using Geographical Information Systems. Journal of Environmental Management 48: 97-110. DOI: 10.1006/ jema.1996.9990.

Egoh B., Dunbar M.B., Maes J., Willemen L., Drakou E.G., 2012. Indicators for mapping ecosystem services: a review. European Commission; Joint Research Centre; Institute for Environment and Sustainability, Ispra, $113 \mathrm{p}$. 
Ehrlich P.R., Ehrlich A.H., 1981. Extinction: the causes and consequences of the disappearance of species. Random House, New York.

European Commission, 2011. Our life insurance, our natural capital: an EU biodiversity strategy to 2020. Brussels, 2011-05-03. COM(2011) 244.

Federici S., Vitullo M., Tulipano S., De Lauretis R., Seufert G., 2008. An approach to estimate carbon stocks change in forest carbon pools under the UNFCCC: the Italian case. iForest 1(1): 86-95.

Fisher B., Turner R.K., Morling P., 2009. Defining and classifying ecosystem services for decision making. Ecological Economics 68(3): 643-653. DOI: 10.1016/ j.ecolecon.2008.09.014.

Fontana V., Radtke A., Bossi Fedrigotti V., Tappeiner U., Tasser E., Zerbe S., Buchholz T., 2013. Comparing land-use alternatives: using the ecosystem services concept to define a multi-criteria decision analysis. Ecological Economics 93: 128-136. DOI: 10.1016/j.ecolecon. 2013.05.007.

Freeman III A.M., 2003. The measurement of environmental and resource values: theory and methods, $2^{\text {nd }}$ edition. Resources for the Future, Washington, $516 \mathrm{p}$.

Garrod G., Willis K., 1999. Economic valuation of the environment. Methods and case studies. Edward Elgar, Cheltenham.

Glück P., Kuen H., 1977. Der Erholungswert des großen Ahornbodens [The recreational value of the large Ahorboden]. Allgemeine Forstzeitung 8(1): 7-11.

Goio I., Gios G., Pollini C., 2008. The development of forest accounting in the province of Trento (Italy). Journal of Forest Economics 14(3): 177-196. DOI: 10.1016/ j.jfe.2007.09.002.

Grilli G., Paletto A., De Meo I., 2014. Economic valuation of forest recreation in an Alpine valley. Baltic Forestry 20(1): 167-175.

Grêt-Regamey A., Walz A., Bebi P., 2008. Valuing ecosystem services for sustainable landscape planning in Alpine regions. Mountain Research and Development 28(2): 156-165. DOI: 10.1659/mrd.0951.

Hanemann W.M., 1994. Valuing the environment through contingent valuation. The Journal of Economic Perspectives 8(4): 19-43. DOI: 10.1257/jep.8.4.19

Hauck J., Schweppe-Kraft B., Albert C., Görg C., Jax K., Jensen R., Fürst C., Maes J., Ring I., Hönigová I., 2013. The promise of the ecosystem services concept for planning and decision-making. GAIA-Ecological Perspectives for Science and Society 22(4): 232-236.

Hawes E., Smith M., 2005. Riparian buffer zones: functions and recommended widths. Yale School of Forestry and Environmental Studies, New Haven, 15 p.

Heal G.M., Barbier E.E., Boyle K.J., Covich A.P., Gloss S.P., Hershner C.H., Hoehn J.P., Pringle C.M., Polasky S., Segerson K., Shrader-Frechette K., 2005. Valuing ecosystems services: toward better environmental decision-making. National Research Council, Washington, D.C.

Hein L., van Koppen K., de Groot R.S., van Ierland E.C.,
2006. Spatial scales, stakeholders and the valuation of ecosystem services. Ecological Economics 57(2): 209228. DOI: 10. 1016/j.ecolecon.2005.04.005.

Hein L., 2011. Economic benefits generated by protected areas: the case of the Hoge Veluwe forest, the Netherlands. Ecology and Society 16(2): 13.

Hönigová I., Vačkář D., Lorencová E., Melichar J., Götzl M., Sonderegger G., Oušková V., Hošek M., Chobot K., 2012. Survey on grassland ecosystem services. Report to the EEA - European Topic Centre on Biological Diversity. Nature Conservation Agency of the Czech Republic, Prague, $78 \mathrm{p}$.

IPCC, 2003. Good practice guidance for land use, Land Use Changes and Forestry, $632 \mathrm{p}$.

Loomis J., 2005. Updated outdoor recreation use values on national forests and other public lands. General Technical Report PNW-GTR-658, USDA, Portland, 26 p.

MA, 2005. Millennium ecosystem assessment ecosystems and human Well-Being: biodiversity synthesis. Wolrd Resources Institute, Washington, 155 p.

Maes J., Egoh B., Willemen L., Liquete C., Vihervaara P., Schägner J.P., Grizzetti B., Drakou E.G., La Notte A., Zulian G., Bouraoui F., Paracchini M.L., Braat L., Bidoglio G., 2012. Mapping ecosystem services for policy support and decision making in the European Union. Ecosystem Services 1(1): 31-39. DOI: 10.1016/ j.ecoser.2012.06.004.

Martínez de Aragón J., Riera P., Giergiczny M., Colinas C., 2011. Value of wild mushroom picking as an environmental service. Forest Policy and Economics 13(6): 419-424. DOI: 10.1016/j.forpol.2011.05.003.

Martínez-Harms M.J., Balvanera P., 2012. Methods for mapping ecosystem service supply: a review. International Journal of Biological Sciences (1-2): 17-25.

Mavsar R., Varela E., Pettenella D., Elizabeth S., Bredahl Jacobsen V., Bredahl Jacobsen J., 2014. The value of carbon sequestration. In: Thorsen J., Mavsar R., Tyrväinen L., Prokofieva I., Stenger A. (eds.), The provision of forest ecosystem services, European Forest Institute (EFI), Joensuu, pp. 56-62.

Merlo M., Rojas Briales E., 2000. Public goods and externalities linked to Mediterranean forests: economic nature and policy. Land Use Policy 17(3): 197-208. DOI: 10.1016/S0264-8377(00)00017-X.

Mitchell R.C., Carson R.T., 1989. Using surveys to value public goods: The contingent valuation method. Hopkins University Press, Washington, 446 p.

Mooney H., Ehrlich P., 1997. Ecosystem services: a fragmentary history. In: Daily G.C. (ed.), Nature's Services, Island Press, Washington. pp. 11-19.

Motta R., Haudemand J.C., 2000. Protective forests and silvicultural stability. Mountain Research and Development 20: 74-81. DOI: 10.1659/0276-4741(2000)020[0180: PFASS] 2.0.CO;2.

Notaro S., Paletto A., Raffaelli R., 2008. The economic valuation of non-productive forest functions as an instrument towards Integrated forest management. EFI Proceedings 55: 301-312. 
Notaro S., Paletto A., 2011. Links between mountain communities and environmental services in the Italian Alps. Sociologia Ruralis 51(2): 137-157. DOI: 10.1111/ j.1467-9523.2011.00532.x.

Notaro S., Paletto A., 2012. The economic valuation of natural hazards in mountain forests: An approach based on the replacement cost method. Journal of Forest Economics 18(4): 318-328. DOI: 10.1016/j.jfe.2012.06.002.

Pak M., Türker M.F., Öztürk A., 2010. Total economic value of forest resources in Turkey. African Journal of Agricultural Research 15(5): 1908-1916.

Paletto A., Ferretti F., Cantiani P., De Meo I., 2012. Multifunctional approach in forest landscape management planning: an application in Southern Italy. Forest Systems 21(1): 68-80. DOI: 10.5424/fs/2112211-11066.

Paletto A., De Meo I., Cantiani M.G., Maino F., 2013. Social perceptions and forest management strategies in an Italian Alpine Community. Mountain Research and Development 33(2):152-160. DOI: 10.1659/MRD-JOURNAL-D-12-00115.1.

Paquette A., Messier C., 2011. The effect of biodiversity on tree productivity: from temperate to boreal forests. Global Ecology and Biogeography 20: 170-180. DOI: 10.1111/j.1466-8238.2010.00592.x.

Peters-Stanley M., Yin D., 2013. Maneuvering the mosaic. State of the voluntary carbon markets 2013. A report by Forest Trends' Ecosystem Marketplace \& Bloomberg New Energy Finance, Washington, 126 p.

Peters-Stanley M., Gonzalez G., 2014. Sharing the stage: State of the voluntary carbon markets 2014 . A report by Forest Trends' Ecosystem Marketplace, Washington.

Rogiers N., Eugster W., Furger M., Siegwolf R., 2005. Effect of land management on ecosystem carbon fluxes at a subalpine grassland site in the Swiss Alps. Theoretical and Applied Climatology 80: 187-203. DOI: 10.1007/ s00704-004-0099-7.

Rosenberger R.S., Loomis J.B., 2001. Benefit transfer of outdoor recreation use values: a technical document supporting the Forest Service Strategic Plan (2000 revision). General Technical Report-Rocky Mountain Research Station. USDA Forest Service RMRS-GTR-72.

Rücker E., 2013. Agrarstrukturerhebung 2010 [Farm structure survey 2010]. Amt der Vorarlberger Landesregierung, Landesstelle für Statistik, Bregenz.

Scarpa R., 1993. System of national sccounts and sustainable development: a review of the issue. Medit 3: 24 31.

Schulze E.D., Wirth C., Heimann M., 2000. Climate change - managing forests after Kyoto. Science 289: 2058-2059. DOI: 10.1126/science.289.5487.2058.
Seidl R., Rammer W., Jägera D., Currieb W.S., Lexer M.J., 2007. Assessing trade-offs between carbon sequestration and timber production within a framework of multi-purpose forestry in Austria. Forest Ecology and Management 248(1-2): 64-79. DOI: 10.1016/ j.foreco.2007.02.035.

Seidel W., Schedler B., Bertel A., 2013. Umsetzungskonzept der Energieregion Leiblachtal [Implementation concept of the energy region Leiblachtal]. Energieinstitut Vorarlberg und Energieregion Leiblachtal. Dornbirn.

Šišák L., 2006. Importance of non-wood forest product collection and use for inhabitants in the Czech Republic. Journal of Forest Science 52(9): 417-426.

Šišák L., 2013. Differentiated valuation of forest services by their relationships to the market and its implementation in the Czech Republic. In: Šišak L., Dudik R., Hrib M. (eds.) Socio-economic analysis of Sustainable Forest Management, Czech University of Life Sciences, Faculty of Forestry and Wood Sciences, Prague. pp. 116-122.

TEEB, 2010. The economics of ecosystems and biodiversity: ecological and economic foundation edited by Pushpam Kumar. An output of TEEB: The economics of ecosystems and biodiversity. Earthscan, Cambridge.

Vitousek P., Mooney H., Lubchenco J., Melilo J., 1997. Human domination of earth's ecosystems. Science 277: 494-499. DOI: 10.1126/science.277.5325.494.

Voces González R., Díaz Balteiro L., López-Peredo Martínez E., 2010. Spatial valuation of recreation activities in forest systems: application to province of Segovia (Spain). Forest Systems 19(1): 36-50. DOI: 10.5424/ fs/2010191-01165.

Vihervaara P., Kumpula T., Tanskanen A., Burkhard B., 2010. Ecosystem services-A tool for sustainable management of human-environment systems. Case study Finnish Forest Lapland. Ecological Complexity 7: 410420. DOI: 10.1016/j.ecocom.2009.12.002.

Westman W., 1977. How much are nature's services worth. Science 197: 960-964. DOI: 10.1126/science.197.4307.960.

Wilhelmsen M., 2009. Samordnet levakårsundersøkelse 2008 - Tverrsnittsundersøkelsen [Coordinated investigation of living conditions 2008]. Dokumentasjonsrapport 2009/40.

Wilson M.A., Hoehn J.P., 2006. Valuing environmental goods and services using benefit transfer: The state-ofthe art and science. Ecological Economics 60(2): 335342. DOI: 10.1016/j.ecolecon.2006.08.015.

Zandersen M., Tol R.S.J., 2009. A meta-analysis of forest recreation values in Europe. Journal of Forest Economics 15: 109-130. DOI: 10.1016/j.jfe.2008.03.006. 
